Pawet KORDOS

\title{
A research stand for the testing of the sealing properties of the piston-rings -cylinder assembly in a combustion engine
}

\begin{abstract}
The paper discusses research assumptions and describes a test stand for the investigations of the sealing properties of the piston rings. The research stand includes an engine brake together with a control system, a research engine and a lubrication and engine thermal state stabilization systems. The engine was fitted with a research piston containing a measuring device enabling the recording of fast varying quantities such as the pressures in the space between the rings, axial displacements of the oil sealing rings in the piston grooves and the temperatures of the gas blown through the seal.
\end{abstract}

Key words: combustion engine, ring seal, gas blow-by, mathematical model, measuring system

\section{Stanowisko do badań uszczelniającego działania układu tlok-pierścienie-cylinder silnika spalinowego}

\begin{abstract}
W artykule omówiono założenia oraz opisano zbudowane stanowisko do badania zjawisk zwiazanych z uszczelniajacym działaniem pakietu pierścieni tłokowych. Stanowisko sktada się z hamulca silnikowego wraz z układem sterowania, silnika badawczego oraz układu smarowania i stabilizacji jego stanu cieplnego. Silnik wyposażony jest w tłok badawczy zawierający układ pomiarowy, umożliwiajacy pomiar i rejestrację szybkozmiennych wielkości, m.in. ciśnień w przestrzeniach międzypierścieniowych, osiowych przemieszczeń pierścieni uszczelniających w rowkach pierścieniowych tłoka oraz temperatur gazu przeptywającego przez uszczelnienie.

Słowa kluczowe: silnik spalinowy, uszczelnienie pierścieniowe, przedmuchy spalin, model matematyczny, układ pomiarowy
\end{abstract}

\section{Introduction}

The design of the piston-rings-cylinder assembly in a piston engine has a decisive influence on the intensity of the gas blow-by to the crankcase, the consumption of engine lubricant and the friction and wear of the elements of the assembly. The design of the said assembly has a key influence on the engine parameters such as its overall efficiency, exhaust emissions, durability and reliability. The ever growing requirements related to the said engine parameters, the fact that engine piston assemblies operate under increasingly severe conditions resulting from ever growing thermal and mechanical loads force the engineers to improve and perfect the design of this particular engine component.

A prerequisite for an effective improvement of the design of a piston-rings-cylinder assembly is the knowledge of the working principle of the ring seal and the ability to predict the impact of the design modifications on its operation under varied conditions. This prediction is difficult due to the complexity of the processes accompanying the sealing. The complexity results from a great number of geometrical parameters and physical features of the seal that significantly influence its efficiency and from the fact that the seal operates under non-steady conditions - a variable linear velocity of the piston and a variable pressure in the sealed space. The results of simulation research conducted on mathematical models are very helpful in predicting the behavior of the piston rings in operation. These models describe the oil film between the rings and the cylinder liner, the flow of gas through the seal and the displacement of the rings in the

\section{Wstęp}

Konstrukcja zespołu tłok-pierścienie-cylinder spalinowego silnika tłokowego decyduje o natężeniu przedmuchów spalin do skrzyni korbowej, ilościowym zużyciu oleju silnikowego oraz procesach tarcia i zużycia zachodzących podczas współpracy elementów zespołu. Konstrukcja ta wpływa więc na kluczowe dla silnika parametry użytkowe, takie jak: sprawność ogólna, emisja toksycznych składników spalin, trwałość i niezawodność. Coraz większe wymagania stawiane silnikom w zakresie wartości ww. parametrów, uwzględnienie coraz trudniejszych warunków pracy elementów układu TPC, co wynika z coraz większych ich obciążeń mechanicznych i cieplnych, powodują, że konstrukcja tego układu musi być ciągle doskonalona.

Warunkiem efektywnego doskonalenia konstrukcji układu TPC jest znajomość zasad działania uszczelnienia pierścieniowego oraz umiejętność przewidywania wpływu zmian konstrukcyjnych na jego zachowanie w różnych warunkach pracy silnika. Przewidywanie to jest trudne ze względu na złożoność procesów towarzyszących działaniu uszczelnienia. Złożoność ta wynika z dużej liczby parametrów geometrycznych i cech fizycznych charakteryzujących uszczelnienie, znacząco wpływających na efektywność jego działania, oraz stąd, że uszczelnienie pracuje w nieustalonych warunkach - zmienna prędkość liniowa tłoka i zmienne ciśnienie w uszczelnianej przestrzeni. Bardzo pomocne $\mathrm{w}$ przewidywaniu zachowania uszczelnienia TPC są wyniki badań symulacyjnych prowadzonych na modelach matematycznych. Modele te m.in. opisują film olejowy pomiędzy 
grooves. The models presented in the literature differ in the number of factors included in the modeling of the blow-by and the way individual phenomena are described.

The mathematical model of the piston-rings-cylinder assembly and its computer application have been developed at Institute of Transport, Combustion Engines and Ecology of Lublin University of Technology [4-6]. The developed model is highly complex and covers the influence of many design factors as well as the wear of the elements on the operation of the piston ring assembly. Yet, despite high complexity of the model, many significant simplifications have been applied. A confrontation of the results of the simulation with the measurement is, thus, necessary to make sure that the applied model is correct. Unfortunately, the empirical data needed for the validation of the model cannot be obtained through a measurement carried out in standard engine tests. Special research methods must be developed.

The paper discusses research assumptions and presents a test stand for the investigations of the phenomena accompanying the operation of the piston rings. The results of the investigations conducted on this test stand will serve the purpose of validating the developed mathematical model of the piston-rings-cylinder assembly.

\section{Model description and assumption for the test stand construction}

In the developed model of the piston ring assembly the authors assumed that the gas flows through a labyrinth composed of many stages connected with damping channels. The individual stages of the labyrinth correspond to the spaces between and behind the rings and the damping channels are the gaps in the joints of the piston rings and the spacing between the lateral surface of the ring and the groove (Fig. 1). The input data introduced to the model are geometrical quantities that provide for the thermal deformations, wear and the course of pressure in the combustion chamber. Based on the introduced input data during the calculations the following are determined as a function of the crankshaft angle: volumes of the individual labyrinth stages, cross-section areas of the damping channels, values of the gas pressures and temperatures in the individual labyrinth stages, axial position of the rings and their twists in the groove (influencing the volumes of the stages and cross-sections of the channels) and the rate of the gas blow-by through the individual gaps in the system (Fig. 1). A detailed description of the model has been presented in [4-6].

Thus far, the results of the measurements of the blowby to the crankcase were used to validate the model. In the simulation the value of the blow-by rate is determined as a result of integration of the instantaneous blow-by rates in the channels directly connected with the crankcase $\left(\mathrm{m}_{5-6}\right.$ and $\mathrm{m}_{5-7}$ in Fig. 1). Hence, the calculated value of the blow-by rate depends on many quantities determined in the model mutually related and differently influencing the calculation of the blow-by rate in the channels. This means that the validation of the model based exclusively on the measurements of the blow-by rate is insufficient as a given value of the blow-by pierścieniami i gładzią cylindrową, przepływ gazu przez uszczelnienie oraz przemieszczenia pierścieni łłokowych w rowkach. Przedstawiane w literaturze modele różnią się zarówno ilością czynników uwzględnianych przy modelowaniu przepływu, jak i sposobem opisu poszczególnych zjawisk.

Matematyczny model uszczelnienia TPC i jego aplikację komputerową opracowano w Instytucie Transportu, Silników Spalinowych i Ekologii Politechniki Lubelskiej [4-6]. Opracowany model cechuje się znacznym stopniem złożoności i pozwala uwzględniać wpływ wielu czynników konstrukcyjnych oraz zużycia elementów na działanie uszczelnienia pierścieniowego. Jednak pomimo dużego skomplikowania modelu, zastosowano w nim wiele znacznych uproszczeń. Konieczna jest więc konfrontacja wyników obliczeń symulacyjnych z wynikami pomiarów, aby upewnić się, czy zastosowany w modelu opis jest poprawny. Niestety, potrzebnych do weryfikacji modelu danych empirycznych nie można uzyskać w pomiarach wykonywanych podczas standardowych badań silnikowych, lecz trzeba opracowywać specjalne metody badawcze.

W artykule omówiono założenia i zaprezentowano zbudowane stanowisko do badań zjawisk towarzyszących uszczelniającemu działaniu układu TPC. Wyniki badań prowadzonych na tym stanowisku posłużą do weryfikacji opracowanego matematycznego modelu uszczelnienia TPC.

\section{Opis modelu i założenia do budowy stanowiska}

W opracowanym modelu uszczelnienia TPC przyjęto, że gaz przepływa przez labirynt składający się z wielu stopni połączonych między sobą kanałami dławiącymi. Poszczególne stopnie labiryntu odpowiadają przestrzeniom między- i zapierścieniowym, a kanały dławiące - szczelinom w zamkach pierścieni i szczelinom pomiędzy bocznymi powierzchniami pierścienia i rowka (rys. 1). Danymi wejściowymi wprowadzanymi do modelu są m.in. wielkości geometryczne, uwzględniające deformacje cieplne i zużycie elementów, oraz przebieg ciśnienia w komorze spalania. Na podstawie wprowadzonych danych wejściowych, w trakcie obliczeń, wyznaczane są w funkcji kąta obrotu wału korbowego m.in.: objętości poszczególnych stopni labiryntu oraz pola przekroju kanałów dławiących, wartości ciśnień i temperatur gazu w poszczególnych stopniach labiryntu, położenia osiowe i skręcenia pierścieni w rowkach (wpływają one na objętości stopni i przekroje kanałów) oraz natężenia przepływu gazu przez poszczególne szczeliny układu (rys. 1). Szczegółowy opis modelu zamieszczono w pracach [4-6].

Dotychczas do weryfikacji modelu wykorzystywano wyniki pomiarów natężenia przedmuchów spalin do skrzyni korbowej. W obliczeniach symulacyjnych wartość masowego natężenia przedmuchów spalin otrzymuje się w wyniku całkowania chwilowych natężeń przepływu w kanałach połączonych bezpośrednio ze skrzynią korbową $\left(\mathrm{m}_{5-6} \mathrm{i}\right.$ $\mathrm{m}_{5-7}$ na rys. 1). A zatem obliczona wartość natężenia przedmuchów spalin jest uzależniona od wielu wyznaczanych w modelu wielkości, w różny sposób od siebie zależnych i w różnym stopniu wpływających na obliczane natężenia przepływu w kanałach. Oznacza to, że weryfikacja modelu 
rate can be obtained with incorrectly determined courses of pressures, ring positions in the grooves etc. Experimental data that would allow a validation of the model would be the courses of those quantities that are determined in the model based on the model assumptions, including physical laws or empirical relations as a function of the crankshaft angle. The values are: gas flow rate through the individual channels, pressures and temperatures of the gas in the individual stages of the labyrinth and positions of the piston rings in the grooves.

The possibilities of measuring of the above quantities on an operating engine have been analyzed. A direct measurement of the blow-by rate through the individual channels has been deemed impossible using the available technical means. No such measurements have ever been described in literature either. The measurement of the gas pressures in the spaces between the rings, the axial displacements of the rings in the grooves and the gas temperatures were, however, technically possible. Literature mentions the measurement of these quantities [1-3, 7-12]. Piezoelectric converters were used most frequently for the measurement of the pressures $[3,8,9,12]$, though a piezo-resistant sensor was mentioned in the literature as well [11]. For the measurement of the axial displacements of the rings in the grooves capacitive $[10,12]$ or induction $[1,7,8]$ sensors were used. The authors decided that the said three quantities would be used for the validation of the model. Unfortunately, literature does not provide any information on any detailed technical solutions regarding the measuring systems. The authors decided to develop their own systems and, subsequently, a test stand enabling the performance of the measurements.
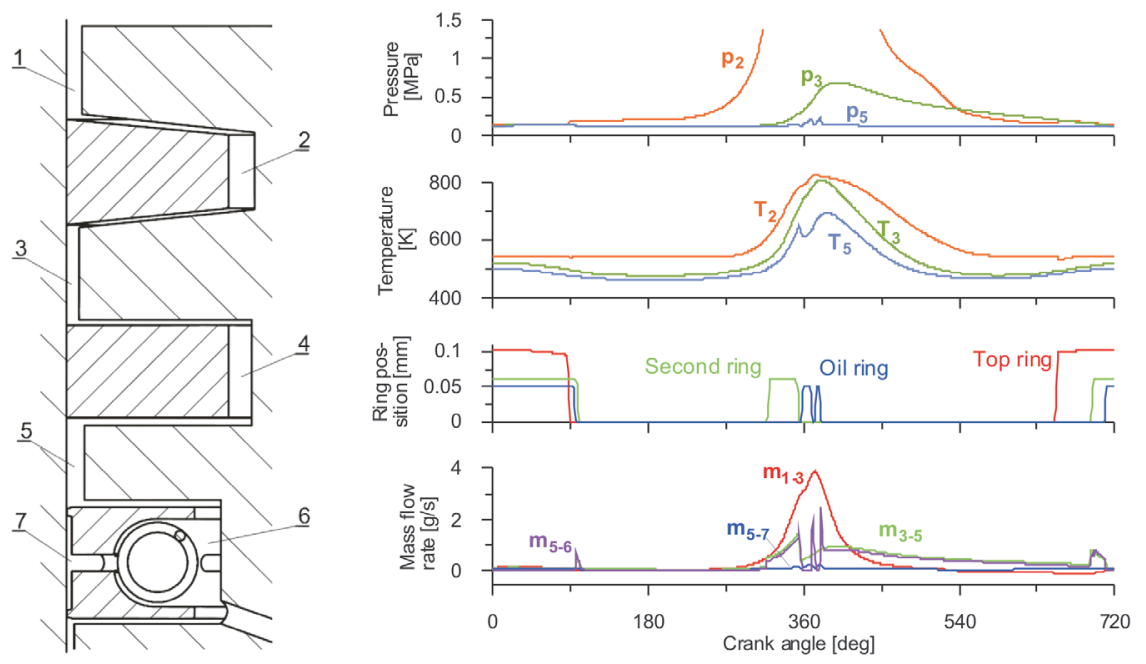

Fig. 1. Schematics of the ring seal and examples of pressure and temperature courses determined in the model in the selected spaces between the rings, axial displacements of the rings in the grooves and gas flow rates through the ring joints and the spacing between the oil scraper ring and the upper surface of the groove

Rys. 1. Schemat uszczelnienia pierścieniowego oraz wyznaczone za pomoca modelu przykładowe przebiegi ciśnień i temperatur gazu w wybranych przestrzeniach międzypierścieniowych, osiowe położenia pierścieni $w$ rowkach oraz natężenia przepływu gazy przez zamki pierścieni i szczeline pomiędzy pierścieniem olejowym i górna płaszczyzną rowka tylko na podstawie pomiarów natężenia przedmuchów spalin jest niewystarczająca, gdyż np. daną, zgodną z pomiarami, wartość natężenia przedmuchów spalin można uzyskać przy niepoprawnie wyznaczonych w symulacjach przebiegach ciśnień, położeń pierścieni w rowkach itd. Dasą wyznaczane w modelu na podstawie przyjętych założeń, w tym praw fizycznych lub zależności empirycznych, w kcji kąta obrotu wału korbowego. Wielkościami takimi nazęenia przepływu gazu przez poszczególne kanały, ciśnienia i temperatury gazu w poszczególnych stopniach iryntu oraz położenia pierścieni w rowkach.

Pzeanalizowano możliwości mierzenia powyżsych za niemożliwy do wykonania przy dostępnych środkach technicznych. Nie spotkano się również ze wzmiankami o takich pomiarach w literaturze. Za możliwe technicznie uznano natomiast wykonanie pomiarów ciśnień gazu w estrzeniach międzypierścieniowych, przemieszczen , choć spotkano się również z wykorzystaniem pojemnościowe $[10,12]$ lub indukcyjne $[1,7,8]$. Podjeto decyzję, że wymienione trzy wielkości wykorzystane będą to weryfikacji modelu. Niestety w literaturze brak jest informacji dotyczących szczegółowych rozwiązań technicznych układów pomiarowych. W związku z powyższym postanowiono opracować własny układ pomiarowy, a następnie stanowisko badawcze umożliwiające wykonanie odpowiednich pomiarów.

Założono, że układ pomiarowy powinien pozwolić na:

a) pomiar ciśnienia $\mathrm{w}$ dwóch przestrzeniach: międzypierścieniowej pomiędzy pierwszym i drugim pierścieniem uszczelniającym oraz za drugim pierścieniem uszczelniającym,

b) pomiar położenia osiowego obu pierścieni uszczelniających,

c) pomiar temperatury gazu $\mathrm{w}$ przestrzeni międzypierścieniowej pomiędzy pierwszym i drugim pierścieniem uszczelniającym.

Ponadto założono, że wszystkie wymienione pomiary powinny być wykonywane równocześnie w pra- 
The authors assumed that the measuring system should allow:

a) the measurement of the pressure in two spaces: the space between the first and the second sealing ring and behind the second sealing ring,

b) the measurement of the axial position of both sealing rings,

c) the measurement of the gas temperature in the space between the first and the second sealing ring.

Besides, the authors assumed that all the mentioned measurements should be carried out at a time on an engine operating with the speed of at least $1500 \mathrm{rpm}$ with the resolution of not less than every $1{ }^{\circ} \mathrm{C}$.A. and it should be possible to record the courses of the said quantities in a minimum of 10 work cycles.

\section{Wireless measuring system and data acquisition system}

The piston selected for the research engine was Mahle 5952800 of the nominal diameter of $102 \mathrm{~mm}$ with three ring grooves and a toroidal combustion chamber with other dimensions as in a piston typically used in the research engine. In a relatively large piston necessary bores were made, measuring converters installed, wire harnesses fitted and space prepared for the measuring system and its power supply (Fig. 2).

Upon the analysis of various solutions of the electrical power supply for the measuring system the authors decided to use a battery pack. The measuring system needs a 7.5 $\mathrm{V}$ power supply with the current of $60 \mathrm{~mA}$. Three Tadiran SL-889 high heat resistance batteries were used. Various methods of data transmission from the system inside the piston to the external recording device were also analyzed (wired connections and radio transmissions). The authors decided to record the data in the internal memory of the measuring system and upon switching off the engine the data were transmitted to a PC by wire.

The measuring system of own design is composed of a set of measuring converters, a data recording module, a power supply module and a PC (Fig. 3). For the pressure measurement AVL GU13X piezoelectric converters were used. These sensors were selected because of their small size and high resistance to accelerations. The signals from the pressure sensors are conditioned by two charge amplifiers enabling the system sensitivity of $10 \mathrm{mV} / \mathrm{bar}$ and a time constant of $0.6 \mathrm{~s}$.

For the measurement of the cującym silniku z prędkością obrotową do, co najmniej, $1500 \mathrm{obr} / \mathrm{min} \mathrm{z}$ rozdzielczością nie mniejszą niż co $1^{\circ}$ kąta obrotu wału korbowego, oraz że powinna istnieć możliwość zarejestrowania przebiegów wyżej wymienionych wielkości w minimum 10 cyklach pracy silnika.

\section{Bezprzewodowy układ pomiarowy i system akwizycji danych}

Jako tłok bazowy dla silnika badawczego wykorzystano tłok Mahle 5952800 o średnicy nominalnej 102 mm z trzema rowkami pierścieniowymi, z toroidalną komorą spalania i pozostałymi wymiarami odpowiadającymi tłokowi pierwotnie stosowanemu w silniku badawczym. We względnie dużym tłoku udało się wykonać niezbędne otwory, zainstalować przetworniki pomiarowe i poprowadzić połączenia oraz przygotować miejsce do zamocowania elektronicznego układu pomiarowego i układu zasilania (rys. 2).

Po analizie różnych rozwiązań zasilania elektrycznego układu pomiarowego zdecydowano się na zastosowanie pakietu baterii. Układ pomiarowy wymaga zasilania napięciem 7,5 V przy poborze prądu około $60 \mathrm{~mA}$. Do zasilania wykorzystano 3 baterie Tadiran SL-889 przystosowane do pracy w wysokich temperaturach. Przeanalizowano również różne metody transmisji danych pomiarowych z układu pomiarowego w tłoku do układu rejestracji na zewnątrz silnika: od połączeń przewodowych do transmisji radiowej. Zdecydowano się na rozwiązanie pośrednie. Podczas pomiaru dane są zapisywane w wewnętrznej pamięci układu pomiarowego, a po zakończeniu pomiaru i zatrzymaniu silnika dane mogą być przesyłane za pomocą transmisji przewodowej i zapisywane w pamięci komputera osobistego.

Zaprojektowany układ rejestracji danych pomiarowych (c)
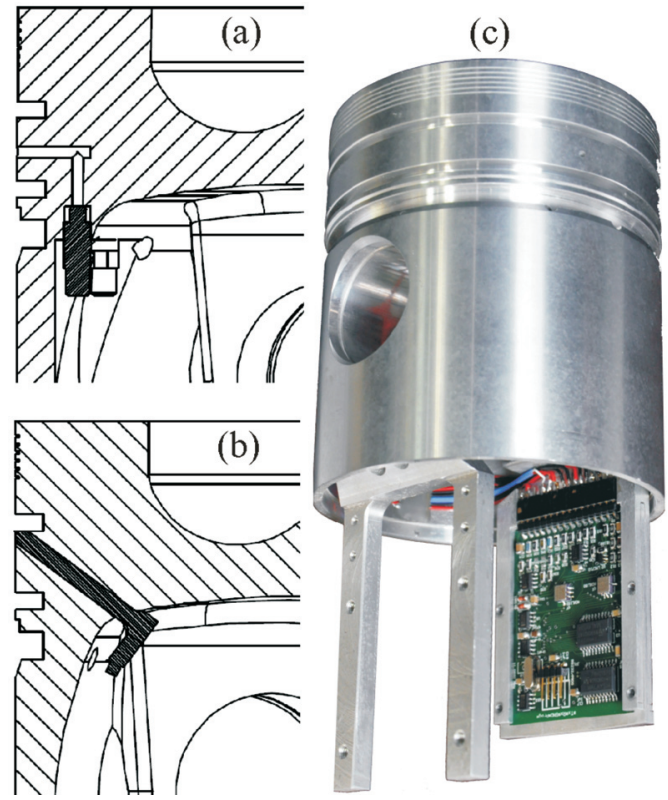

Fig. 2. The piston with the measuring system installed: cross-section of the pressure sensor (a), cross-section of the distance sensor (b), the piston (c)

Rys. 2. Tłok z zainstalowanym uktadem pomiarowym: przekrój przez czujnik ciśnienia (a), przekrój przez czujnik odległości (b) oraz tłok (c) składa się z zestawu przetworników pomiarowych, modułu rejestracji danych, modułu zasilania oraz komputera osobistego (rys. 3). Do pomiaru ciśnienia wykorzystano piezoelektryczne przetworniki ciśnienia AVL GU13X. Czujniki te wybrano ze względu na małe wymiary oraz bardzo małą czułość na przyspieszenia. Sygnały ładunku z czujników ciśnienia kondycjonowane są za pomocą dwóch wzmacniaczy ładunku, pozwalających uzyskać czułość układu pomiarowego $10 \mathrm{mV} /$ bar i stałą czasową układu $0,6 \mathrm{~s}$.

Do pomiaru położenia osiowego pierścieni tłokowych w rowkach wykorzystano specjalnie zaprojektowane przetworniki pomiarowe. Każdy z przetworników składa się z mostka magnetycznego łączącego półkę rowka pierścieniowego z wewnętrzną powierzchnią płaszcza tłoka. Na końcu mostka magnetycznego znajduje się liniowy czujnik hallotro- 
axial position of the rings in the grooves specially designed measurement converters were applied. Each of the converters has a magnetic bridge connecting the shelf of the groove with the inner space of the piston skirt. At the end of the magnetic bridge there is a linear hallotronic sensor and a permanent magnet. Such a solution not only allows the identification of the piston end positions but also its displacement.

For the measurement of the temperatures two thermocouples were used fitted in a specially made recess between the rings. In order to obtain a required response time of the temperature measuring system, special $\mathrm{K}$ type thermocouples fitted with a thin wire and having low mass of the seams were used.

The measuring system was also fitted with two integrated ADXL 193 accelerometers by Analog Devices of the measuring range of $250 \mathrm{~g}$. The accelerometers were installed for the measurement of the piston acceleration in the direction

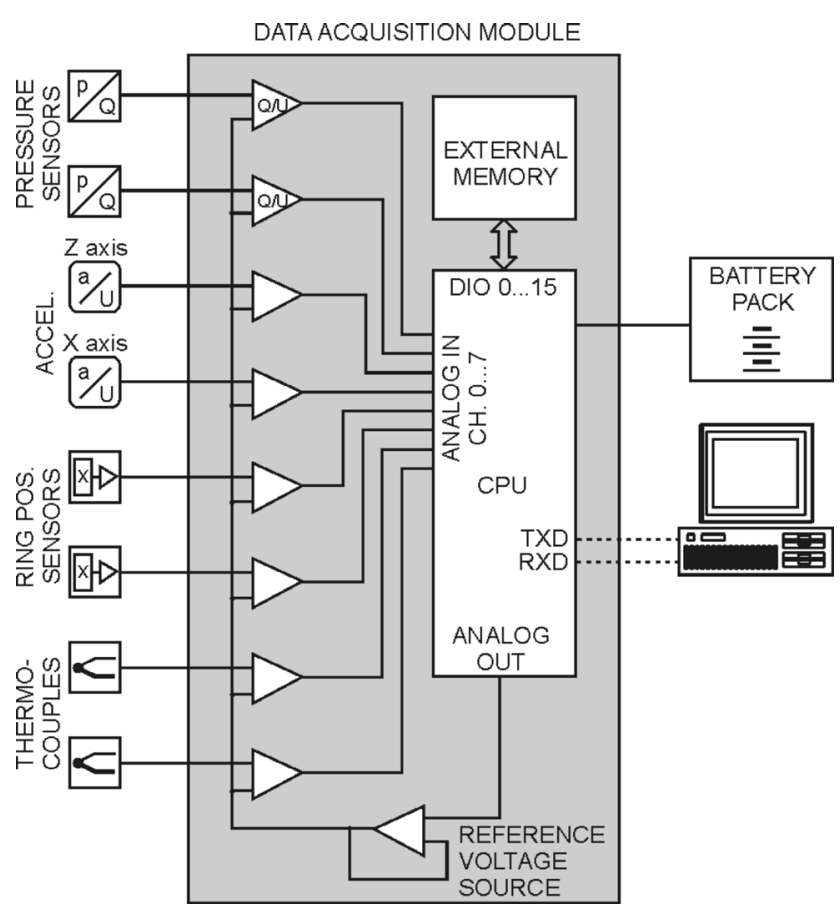

Fig. 3. Diagram of the measuring system Rys. 3. Schemat blokowy układu pomiarowego

parallel to the cylinder axis and perpendicular to the cylinder and wristpin axis. The acceleration values were used to determine the relations between the results of the measurements from all other sensors and crankshaft angle.

The conditioned analog signals are sent to a 12-bit analog/ digital converter of the maximum sampling frequency of 400 $\mathrm{kHz}$. The analog/digital converter is integrated with a micro controller. The results of the conversions are saved in the memory of the capacity of 300000 samples. The capacity of the memory is sufficient to save data from 50 engine working cycles with the angular resolution of $1^{\circ} \mathrm{C}$.A.

The measuring system was completed on a four-layer $50 \times 60 \mathrm{~mm}$ circuit board. The second module of the same dimensions holds a battery pack. The electronic systems are fitted with special holders in the lower part of the piston on nowy oraz magnes trwały. Takie rozwiązanie pozwoliło nie tylko na identyfikację krańcowych położeń pierścienia, lecz również na ocenę odległości.

Do pomiaru temperatur zastosowano dwie termopary umieszczone w specjalnie wykonanych zagłębieniach pomiędzy pierścieniami. Aby uzyskać odpowiedni czas odpowiedzi układu pomiarowego temperatury, zastosowano specjalne termopary typu $\mathrm{K}$ charakteryzujące się cienkim drutem oraz małą masą spoin.

Ponadto układ pomiarowy wyposażono w dwa scalone akcelerometry typu ADXL 193 produkcji firmy Analog Devices o zakresie pomiarowym $250 \mathrm{~g}$. Akcelerometry te służą do pomiaru przyspieszenia tłoka $\mathrm{w}$ kierunkach równoległym do osi cylindra oraz prostopadłym do osi cylindra i osi sworznia tłokowego. Zmierzone wartości przyspieszeń wykorzystane będą do ustalenia zależności pomiędzy przebiegami wyników pomiarów uzyskanych z pozostałych przetworników a kątem obrotu wału korbowego.

Kondycjonowane sygnały analogowe przesyłane są do 12-bitowego przetwornika analogowo-cyfrowego o maksymalnej częstotliwości próbkowania $400 \mathrm{kHz}$. Przetwornik analogowo-cyfrowy zintegrowany jest w mikrokontrolerze. Wyniki przetwarzania zapisywane są w pamięci o pojemności 300000 próbek. Taka pojemność pamięci wystarcza na zapisanie danych z 50 cykli pracy silnika przy rozdzielczości kątowej pomiaru $1^{\circ} \mathrm{OWK}$.

Układ pomiarowy zmontowano na czterowarstwowej płytce drukowanej o wymiarach $50 \times 60 \mathrm{~mm}$. W drugim module o tych samych wymiarach znajduje się blok baterii. Układy elektroniczne zamontowane są w specjalnych uchwytach w dolnej części tłoka po obu stronach korbowodu (rys. 2c). Aby zabezpieczyć układy elektroniczne przed działaniem bardzo dużych przyspieszeń oraz zanieczyszczeń mogących znajdować się w oleju silnikowym, płytki elektroniczne zabezpieczono warstwą żywicy.

Sygnały z ruchomego układu rejestracji danych przesyłane są do komputera osobistego za pomocą transmisji szeregowej. Odczytywanie danych pomiarowych odbywa się po zatrzymaniu silnika. Pierwszym etapem procesu rejestracji sygnałów jest zaprogramowanie układu pomiarowego. Programowanie układu polega na ustaleniu częstotliwości próbkowania oraz sekwencji kanałów pomiarowych. Możliwe jest uzyskanie różnych częstotliwości próbkowania poszczególnych kanałów, w zależności od charakteru zmian poszczególnych wielkości. Oprogramowanie umożliwia ustawienie czasu zwłoki przed automatycznym rozpoczęciem pomiarów. Jest to czas na przygotowanie i uruchomienie silnika badawczego. Po zakończeniu pomiarów silnik należy zatrzymać i można przystąpić do odczytywania danych pomiarowych.

\section{Badania układu pomiarowego}

Po wykonaniu układu pomiarowego poddano go wstępnym badaniom polegającym na rejestracji sygnałów pomiarowych bez poddawania modułu elektronicznego działaniu przyspieszeń i wysokiej temperatury. W celu weryfikacji działania układu pomiaru położenia osiowego pierścieni tłokowych w rowkach, tłok badawczy z pierścieniami umieszczono w tulei cylindrowej. Podczas rejestracji sygnałów tłok 
both sides of the connecting rod (Fig. 2c). In order to secure the electronic systems against extremely high accelerations and contaminants from the engine lubricant the electronic boards were covered with resin.

The signals from the movable data recording system are sent to the PC through a serial transmission. The measurement data are pulled from the device after the engine is stopped. The first stage of the signal recording process is programming of the measuring system. The programming consists in setting the sampling frequency and the sequence of the measuring channels. It is possible to set different sampling frequencies of the individual channels depending on the nature of the changes of the individual quantities. The software enables setting of the delay time before the automatic measurement starts. This is the time needed for the research engine preparation and its subsequent start. After the measurements are finished the engine is stopped and the measurement data can be pulled from the system.

\section{Testing the measuring system}

Upon completion of the construction of the measuring system it was subjected to preliminary tests consisting in the recording of the measurement signals without subjecting the measuring module to high accelerations and temperature. In order to check the operation of the system measuring the axial position of the piston rings in the grooves the research piston with the ring was placed in the cylinder sleeve. During the recording of the signals the piston was moved in the sleeve for the axial displacement of the piston rings to occur. The results of the measurements have been presented in Fig. 4. The data recording was conducted with the sampling frequency of $6.67 \mathrm{kHz}$. The proposed solution of the measuring system allows not only the identification of the end positions of the piston rings on the shelves but also a continuous distance measurement.

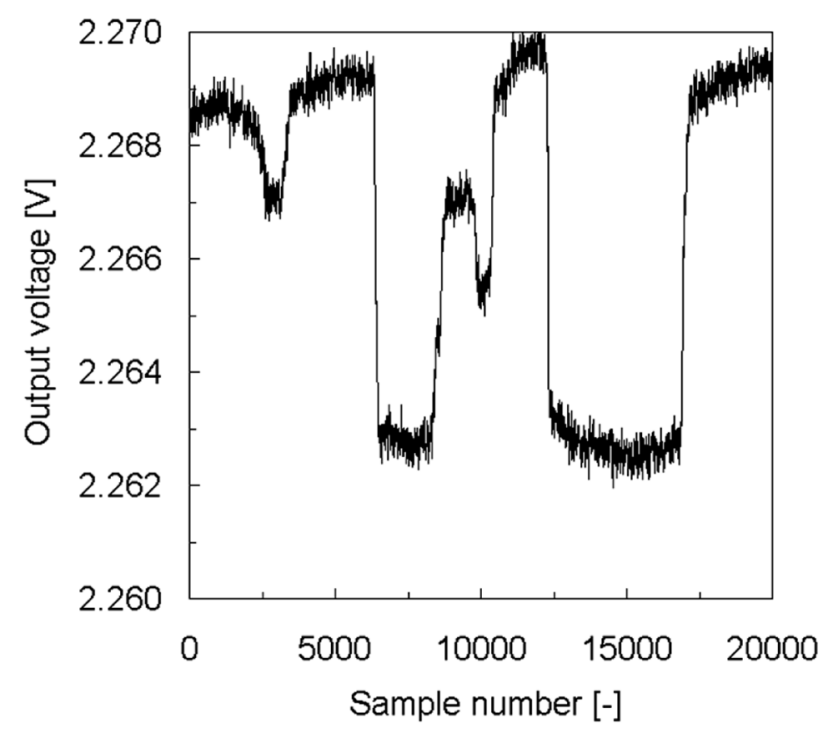

Fig. 4. The tracking of the output voltage of the piston ring position sensor

Rys. 4. Przebieg napięcia wyjściowego czujnika położenia pierścienia tlokowego był poruszany w tulei tak, aby następowało przemieszczanie osiowe pierścieni. Wyniki pomiarów przedstawiono na rys. 4. Rejestrację danych prowadzono z częstotliwością próbkowania $6,67 \mathrm{kHz}$. Zaproponowane rozwiązanie układu pomiarowego pozwala nie tylko na identyfikację skrajnych położeń pierścienia na półkach rowka pierścieniowego, ale także na ciągły pomiar odległości.

Weryfikację układu do pomiaru ciśnienia pomiędzy pierścieniami przeprowadzono, wykorzystując sygnał z czujnika zamontowanego w komorze spalania pracującego silnika. Badania wykonano na jednocylindrowym silniku o zapłonie iskrowym pracującym ze stałą prędkością obrotową 2500 obr/min i przy małym obciążeniu rzędu 0,3 MPa średniego ciśnienia indykowanego. Wyniki pomiarów (rys. 5) wykazały, że uzyskano wystarczająco dobrą jakość sygnału. Dane rejestrowane były z częstotliwością $66,7 \mathrm{kHz}$.

Przeprowadzone próby wykazały, że pakiet baterii umożliwia ciągłą pracę układu pomiarowego przez co najmniej $40 \mathrm{~min}$.

Kolejny etap badań układu pomiarowego polegał na sprawdzeniu jego odporności na przyspieszenia. Do tego celu wykorzystano mechanizm odtwarzający kinematykę tłoka w silniku badawczym. Badania przeprowadzono przy prędkości obrotowej wynoszącej 600 obr/min. Na rysunku 6 przedstawiono zarejestrowane przebiegi przyspieszeń.

\section{Adaptacja jednocylindrowego silnika badawczego}

Do badań wykorzystano jednocylindrowy silnik badawczy o zapłonie samoczynnym z bezpośrednim wtryskiem do komory spalania. Średnica cylindra silnika wynosi $102 \mathrm{~mm}$, a skok tłoka $-100 \mathrm{~mm}$. Silnik posiada dwa zawory na cylinder $\mathrm{z}$ pośrednim napędem i wałkiem rozrządu umieszczonym $\mathrm{w}$ górnej części obudowy tulei cylindrowej. Napęd na wałek rozrządu $\mathrm{z}$ wału korbowego przenoszony jest wałkiem królewskim. Silnik ma możliwość płynnej regulacji stopnia sprężania w zakresie od 16 do 22,4.

Pierwotna konstrukcja silnika nie umożliwiała jednak zainstalowania tłoka badawczego. Ze względu na małą odległość pomiędzy korbowodem i przeciwciężarami nie było możliwości, aby elementy układu pomiarowego zmieściły się w tej przestrzeni przy dolnym położeniu tłoka. Oznaczało to konieczność dokonania znacznej modyfikacji silnika badawczego - wymaganą ilość miejsca uzyskano dzięki wydłużeniu korbowodu i podwyższeniu tulei cylindrowej wraz z głowicą. Uzyskano to dzięki zastosowaniu specjalnej tulei. Oprócz tej tulei i korbowodu, opracowano konstrukcję i wykonano wydłużony wałek królewski do napędu rozrządu oraz jego obudowę i inne niezbędne elementy silnika.

Ponadto w głowicy silnika wykonano otwór umożliwiający mocowanie czujnika do pomiaru ciśnienia w komorze spalania. Kadłub silnika przed i po modyfikacji przedstawiono na rys. 7 .

\section{Stanowisko dynamometryczne}

Silnik badawczy zainstalowano na odpowiednio przygotowanym stanowisku do badań dynamometrycznych. Do obciążania i napędzania silnika wykorzystano hamulec 


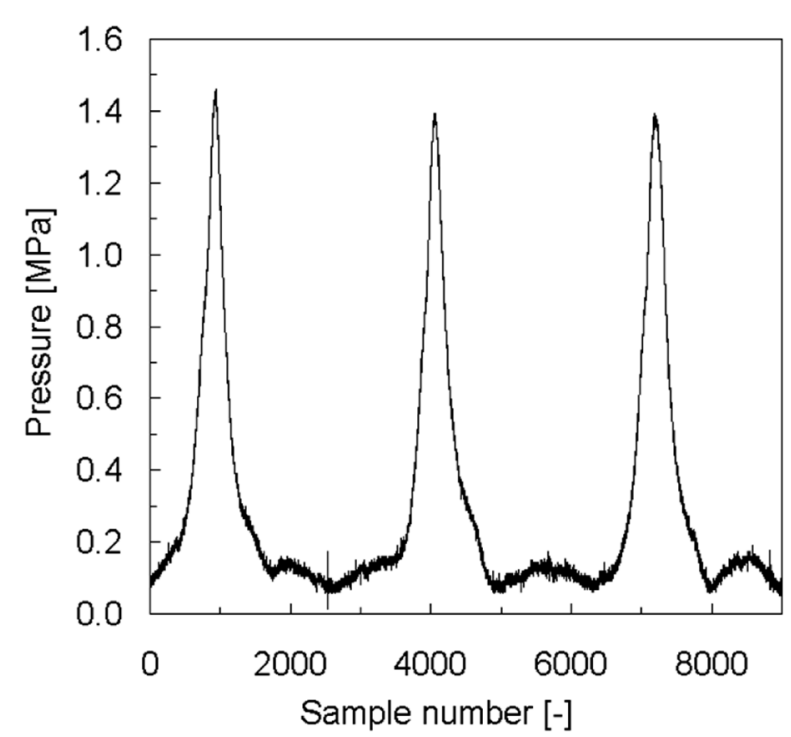

Fig. 5. The tracking of the indicated pressure inside the engine cylinder Rys. 5. Przebieg ciśnienia indykowanego w cylindrze silnika

The checking of the measuring system of the pressure between the piston rings was carried out using a signal from the sensor fitted in the engine combustion chamber. The tests were carried out on a single cylinder spark ignition engine working with a constant speed of $2500 \mathrm{rpm}$ at a small load of $0.3 \mathrm{MPa}$ of the mean indicated pressure. The results of the measurements (Fig. 5) have shown that a sufficient signal quality was obtained. The data was recorded with the frequency of $66.7 \mathrm{kHz}$.

The performed trackings have shown that the battery pack allows a continuous operation of the measuring device for at least 40 minutes.

Another stage of the tests of the measuring device consisted in checking its resistance to accelerations. For this reason a mechanism reproducing the kinematics of the piston in the research engine was used. The tests were carried out at the engine speed of $600 \mathrm{rpm}$. Figure 6 presents the recorded tracking of the accelerations.

\section{The course of the piston acceleration in the research engine}

For the tests the authors used a single cylinder direct injected diesel research engine. The cylinder bore is 102 $\mathrm{mm}$ and the displacement $-100 \mathrm{~mm}$. The engine has two valves per cylinder with an indirect drive and a camshaft in the upper part of the cylinder sleeve casing. The drive of the camshaft is transferred from the crankshaft through an intermediate distribution shaft. The engine compression ratio can be smoothly adjusted in the range from 16 to 22.4.

The initial design of the engine did not allow installing the research piston. Due to a small distance between the connecting rod and the counterweights the components of the measuring system would not fit if the piston reached its lowest position. This forced a serious modification of the research engine - the required space was made thanks to the extension of the connecting rod and the extension of the cyl- silnikowy, którym jest maszyna prądu stałego o mocy pochłanianej $80 \mathrm{~kW}$.

Ze względu na specyfikę planowanych badań, w szczególności biorąc pod uwagę trwałość układu pomiarowego, założono, że silnik z zamontowanym tłokiem badawczym powinien pracować jak najkrócej, stąd układ chłodzenia silnika powinien pozwalać na wstępne podgrzanie niepracującego silnika. Aby sprostać tym wymaganiom, wykonano układ chłodzenia z opcją ogrzewania zarówno cieczy chłodzącej, jak i oleju z automatyczną regulacją temperatury. Układ ten wyposażony jest w zewnętrzne pompy cyrkulacyjne umożliwiające uzyskanie odpowiedniej temperatury bez konieczności napędzania silnika (rys. 8).

Do pomiaru zużycia paliwa zastosowano grawimetryczny miernik zużycia paliwa, natomiast do pomiaru natężenia przedmuchów spalin urządzenie AVL Blow-By Meter 442. Ponadto stanowisko badawcze wyposażono w przetworniki pomiarowe oraz panele odczytowe następujących wielkości wolnozmiennych: temperatury powietrza na dolocie do silnika, temperatury spalin, temperatury cieczy chłodzącej, temperatury i ciśnienia oleju. Do wyznaczania ilości powietrza zasysanego przez silnik zastosowano metodę pośrednią - strumień masy powietrza wyznaczany jest na podstawie masowego zużycia paliwa oraz wskazań szerokozakresowej sondy lambda zainstalowanej w układzie wylotowym.

\section{Podsumowanie}

Opracowano unikatowy układ pomiarowy pozwalający na wyznaczenie zmian w czasie cyklu pracy silnika następujących wielkości: ciśnień w dwóch wybranych przestrzeniach międzypierścieniowych, przemieszczeń osiowych pierścieni uszczelniających w rowkach tłoka oraz temperatury gazu przepływającego przez uszczelnienie pierścieniowe. Układ ten, składający się z czujników pomiarowych, modułu przetwarzającego i rejestrującego

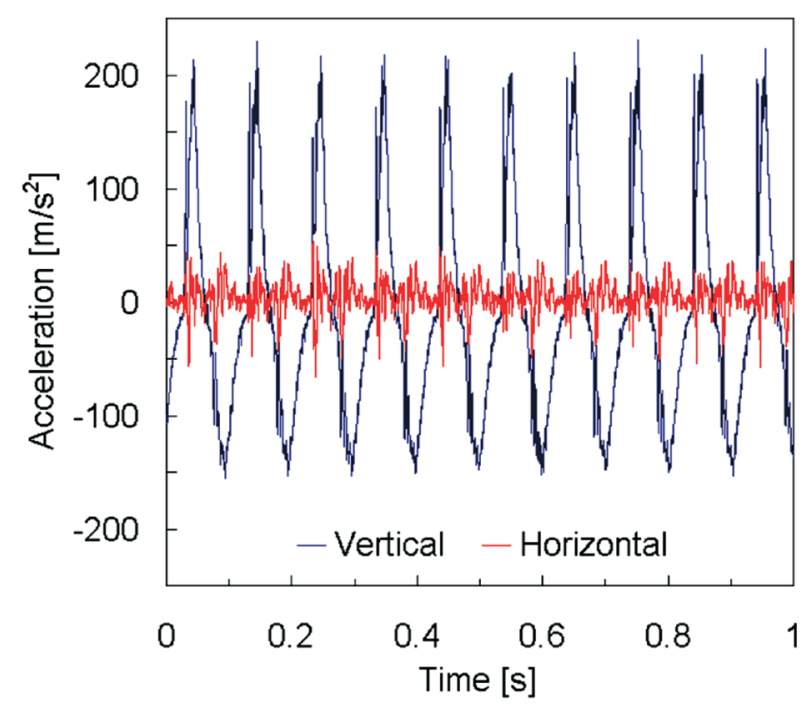

Fig. 6. The tracking of the piston acceleration at the engine speed of $600 \mathrm{rpm}$

Rys. 6. Przebieg przyspieszenia tłoka przy prędkości obrotowej $600 \mathrm{obr} / \mathrm{min}$ 
inder sleeve with the cylinder head. A special sleeve allowed such a modification. Beside the sleeve and the connecting rod, an extended intermediate distribution shaft for the timing system, its casing and other necessary engine elements were designed and built.

In the engine cylinder head a hole was made for the fitting of the combustion chamber pressure sensor. The engine block before and after the modification has been shown in Fig. 7.

\section{Dynamometer stand}

The research engine was installed on a dynamometer stand. A direct current electric machine of the absorbated power of $80 \mathrm{~kW}$ was used to load and drive the engine.

Due to the specificity of the planned research tasks, particularly as regards the durability of the measuring system, the authors assumed that the engine with the installed research piston should work for the shortest possible time, hence the engine cooling system should provide engine heating before it starts operation. To do this, the cooling system was equipped with an adjustable heating option of both the coolant and the oil. This system has external circulation pumps allowing an obtainment of the desired temperatures without the necessity to start the engine (Fig. 8).

For the measurement of the fuel consumption a gravimetric fuel meter was used and for the measurement of the blow-by rate the authors used AVL Blow-By Meter 442. The test stand was also fitted with a measurement converter and readout panels of the following slow varying quantities: intake air temperature, exhaust gas temperature, coolant temperature, oil temperature and oil pressure. To calculate the amount of air taken by the engine an indirect method was applied - a mass flow is calculated based on mass fuel consumption and the signal from a wideband oxygen sensor (lambda) installed in the exhaust system.

\section{Conclusions}

A unique measurement system was developed that allows determining of the changes of the following quantities during the engine work cycle: pressure in two selected spaces between the rings, axial sealing rings displacements in the ring grooves and the temperature of the gas blown through the ring seal. This system (composed of measuring sensors, a processing and a recording modules and a power module) was installed in a piston of a modified single cylinder diesel research engine. The engine was installed on a dynamometer stand fitted with an external cooling and lubrication systems that ensured maintaining of the required engine thermal conditions.

sygnały pomiarowe oraz modułu zasilającego, umieszczono w tłoku zmodyfikowanego jednocylindrowego badawczego silnika o zapłonie samoczynnym. Silnik zamontowano na odpowiednio przystosowanym stanowisku dynamometrycznym, wyposażonym m.in. w zewnętrzny układ chłodzenia i smarowania, pozwalający utrzymać silnik w wymaganym stanie cieplnym.

Układ pomiarowy poddano testom sprawdzającym. Elektroniczny układ kondycjonowania i rejestracji sygnałów pomiarowych spełniał wszystkie wymagania metrologiczne w zakresie częstotliwości próbkowania, rozdzielczości pomiarowej oraz jakości subminiaturowych układów kondycjonowania sygnałów. Sprawdzono także odporność

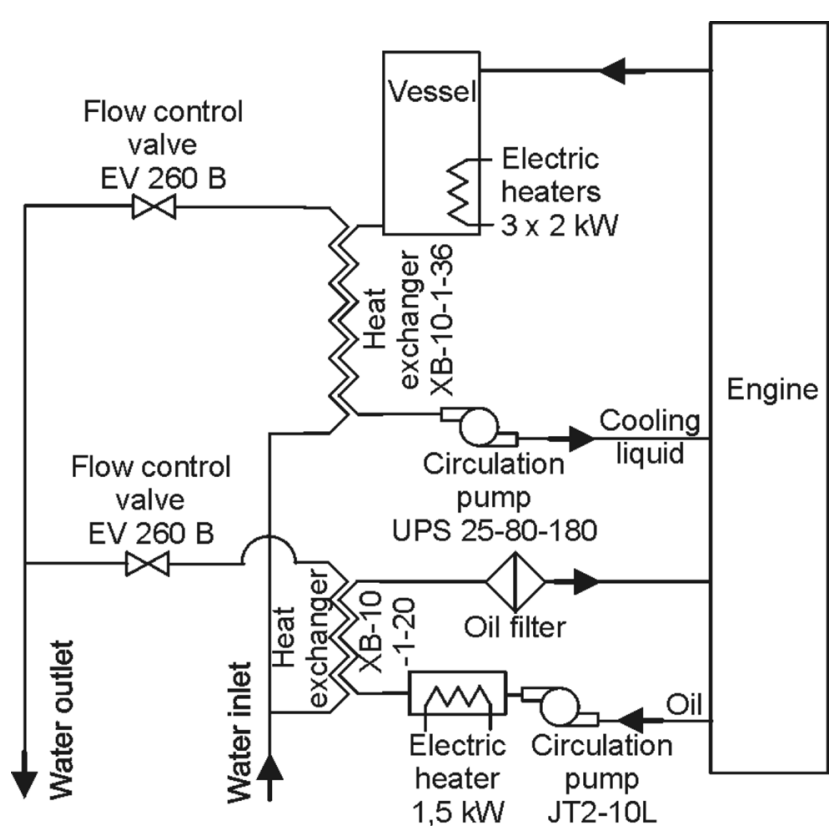

Fig. 8. Schematics of a hydraulic engine temperature stabilization system

Rys. 8. Schemat hydraulicznego układu stabilizacji temperatury silnika 
The measurement system was subjected to a checkup. The electronic system for the measurement signal conditioning and recording met all the metrological requirements in terms of the sampling frequency, measurement resolution and quality of the subminiature signal conditioning systems. The resistance of the system to high temperatures of up to $100{ }^{\circ} \mathrm{C}$ and high g-loads of up to $200 \mathrm{~g}$ was also checked (due to technological limitations the system could not have been subjected to thermal and mechanical loads at a time). The trial confirmed the correct selection of the power supply system. The tests performed on the measurement system, on the research engine and on the dynamometer stand have confirmed their full compliance with the set requirements.

The test stand should allow measuring of the fast varying quantities accompanying the sealing of the piston-ringscylinder assembly during a regular engine operation at varied engine speeds and loads. The results of the measurements will serve the purpose of validating the mathematical model of the piston ring seal.

\section{Bibliography/Literatura}

[1] Ariga S.: Observation of Transient Oil Consumption with InCylinder Variables, SAE Paper 961910, 1996.

[2] Chen J.: Richardson D.E., Predicted and Measured Ring Pack Performance of a Diesel Engine, SAE Paper 2000-01-0918, 2000.

[3] Dursunkaya Z., Keribar R., Richardson D.E.: Experimental and Numerical Investigation of Inter-Ring Gas Pressures and Blowby in a Diesel Engine, SAE Paper 930792, 1993.

[4] Koszałka G.: Heat transfer between gas and the surrounding walls in the model of gas flow from the combustion chamber to the crankcase, Combustion Engines 3(138), pp. 71-79, 2009.

[5] Koszałka G.: Application of the piston-rings-cylinder kit model in the evaluation of operational changes in blowby flow rate,

Grzegorz Koszałka, DEng. - doctor in the Faculty of Mechanical Engineering at Lublin University of Technology.

Dr inż. Grzegorz Koszatka - adiunkt na Wydziale Mechanicznym Politechniki Lubelskiej.

e-mail: g.koszalka@pollub.pl

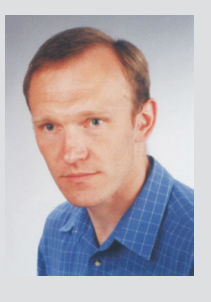

Jacek Hunicz, DSc., DEng. - professor in the Faculty of Mechanical Engineering at Lublin University of Technology.

Dr hab. inż. Jacek Hunicz, prof. PL - profesor na Wydziale Mechanicznym Politechniki Lubelskiej.

e-mail: j.hunicz@pollub.pl

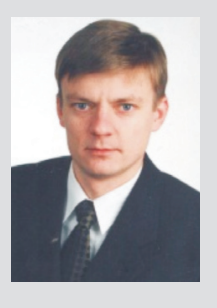

układu na działanie wysokich temperatur do $100{ }^{\circ} \mathrm{C}$ oraz dużych przeciążeń do $200 \mathrm{~g}$ - ze względu na ograniczenia techniczne układ nie był poddany jednocześnie działaniu obciążeń cieplnych i mechanicznych. Próby potwierdziły również poprawność wyboru układu zasilającego. Przeprowadzone testy układu pomiarowego, silnika badawczego i stanowiska dynamometrycznego potwierdziły, że spełniają one postawione wymagania.

Przygotowane stanowisko powinno umożliwić dokonanie pomiarów szybkozmiennych wielkości towarzyszących uszczelniającemu działaniu układu TPC podczas normalnej pracy silnika, przy różnych prędkościach obrotowych i różnych obciążeniach. Wyniki pomiarów posłużą do weryfikacji opracowanego matematycznego modelu uszczelnienia pierścieniowego.

\section{Acknowledgements}

This work has been financed from resources appropriated for science in the years 2010-2012 as a research project no. N N509 479538/Praca finansowana ze środków na naukę w latach 20102012 jako projekt badawczy nr N N509 479538
Eksploatacja i Niezawodnosc - Maintenance and Reliability $\mathrm{Nr}$ 4(48), pp. 72-81, 2010.

[6] Koszałka G.: Predicting the durability of the piston-ringscylinder assembly of a diesel engine using a piston ring pack model, Eksploatacja i Niezawodnosc - Maintenance and Reliability 3(51), pp. 40-44, 2011.

[7] Nakayama K., Yasutake Y., Takiguti M., Furuham: S., Effect of Piston Motion on Piston Skirt Friction of a Gasoline Engine. SAE Paper 970839, 1997.

[8] Petris De C., Giglio V., Police G.: Some Insights on Mechanisms of Oil Consumption, SAE Paper 961216, 1996.

[9] Richardson D.E.: Comparison of Measured and Theoretical Inter-Ring Gas Pressure on a Diesel Engine. SAE Paper 961909, 1996.

[10] Takiguchi M., Ando H., Takimoto T., Uratsuka A.: Characteristics of Friction and Lubrication of Two-Ring Piston, JSAE Review 17, pp. 11-16, 1996.

[11] Tamminen J., Sandstrom C-E., Andersson P.: Influence of load on the tribological conditions in piston ring and cylinder liner contacts in a medium-speed diesel engine, Tribology International 39, pp. 1643-1652, 2006.

[12] Yoshida H., Yamada M., Kobayashi H.: Diesel Engine Oil Consumption Depending on Piston Ring Motion and Design, SAE Paper 930995, 1993.

Paweł Kordos, DEng. - doctor in the Faculty of Mechanical Engineering at Lublin University of Technology.

Dr inż. Pawet Kordos - adiunkt na Wydziale Mechanicznym Politechniki Lubelskiej.

e-mail: p.kordos@pollub.pl

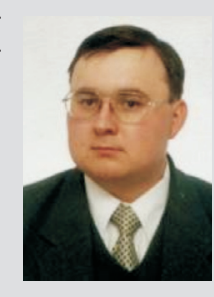

